\title{
Congenital nasolacrimal duct obstruction: Clinical, microbiological and management in a tertiary health care centre in central India- A descriptive study
}

\author{
Piyush Madan ${ }^{1, *}$, Sachin Daigavane ${ }^{2}$ \\ ${ }^{1}$ PG Student, ${ }^{2}$ Professor and HOD, Dept. of Ophthalmology J.N.M.C. Sawangi (MEGHE) Wardha, Maharashtra, India \\ *Corresponding Author: \\ Email: pmadan01@gmail.com
}

\begin{abstract}
Introduction: Congenital nasolacrimal duct has accounts for $6 \%$ of newborn infants with various treatment. Microbiological studies to identify the type of species involved in Lacrimal Sac infection secondary to Congenital Nasolacrimal Duct Obstruction (CNLDO) have been extensively reposted.

Aims and Objective: to assess microorganisms causing congenital nasolacrimal duct obstruction. To see efficacy of probing as compared to silastic intubation.

Materials and Methods: A total 100 patients were enrolled in the study. The patients came with epiphora and mucous discharge. Inclusion criteria for the study was patients presenting with CNLDO (Presence of atleast one sign of NLDO: Epiphora, increased tear lake, and/or mucopurlent discharge), Age upto 9 years.

Exclusion Criteria: Punctual or canalicular abnormality, H/o previous surgery, H/o faciomaxillary trauma, cleft lip/ cleft palate or any facial deformity, acute dacryocystitis, previous history of probing. Sample size was 100 patients.

Results: Haemophilus influenzae and streptococcus pneumonia were the most common microorganisms $(n=56,40.5 \%$; $=37$, $26.8 \%$ respectively) followed by moraxella catarrhalis $(n=19,13.7 \%)$, staphylococcus aureus $(n=17,12.3 \%)$, pseudomonas aeruginosa $(n=9,0.65 \%)$.

Discussion: Congenital nasolacrimal duct obstruction results in stagnation of fluid within the lacrimal sac area which causes secondary bacterial infection. The prevalence of CNLDO with no growth shows the sole effect of congenital anomaly on the degree of tightness.
\end{abstract}

Conclusion: The mocobiological study of CNLDO may have a value in predicting the obstruction.

Keywords: Acute dacryocystitis, Congenital nasolacrimal duct Obstruction.

\section{Introduction}

Lacrimal apparatus consists of the lacrimal gland, the accessory glands and the lacrimal passage. Lacrimal passage consists of lacrimal puncta, lacrimal canaliculi, lacrimal sac and nasolacrimal duct. Obstruction of lacrimal passage may occur at any level: punctum, canaliculus, lacrimal sac and NLD. Congenital nasolacrimal duct has accounts for $6 \%$ of newborn infants with various treatment. ${ }^{1}$ Spontaneous resolution seen in $80-96 \%$ infants by one year. ${ }^{2}$ Conservative treatment is consider effective in first year of life which includes frequent lacrimal sac massage and topical antibiotics. ${ }^{3}$ Surgical probing or silastic intubation performed to overcome unresolved obstruction. ${ }^{4}$ Nasolacrimal duct (NLD) obstruction, whether congenital or acquired, predisposes lacrimal drainage system (LDS) to secondary bacterial infection due to stagnation of the tear secondary bacterial infection due to stagnation of tear within LS. ${ }^{5}$ Microbiological studies to identify the type of species involved in Lacrimal Sac infection secondary to Congenital Nasolacrimal Duct Obstruction (CNLDO) have been extensively reposted.

\section{Aims and Objective}

1. To assess microorganisms causing congenital nasolacrimal duct obstruction.

2. To see efficacy of probing as compared to silastic intubation.

\section{Materials and Methods}

The study was conducted with the objective of comparing the clinical presentation of CNLDO in urban and rural population, Isolation and culture sensitivity of different microorganisms that are causing CNLDO, to compare the medical and surgical management outcome. It was a prospective, interventional study conducted for 2 years at Acharya Vinobha Bhave Rural Hospital Sawangi, Wardha.

Inclusion Criteria: for the study was patients presenting with CNLDO (Presence of atleast one sign of NLDO: Epiphora, increased tear lake, and/or mucopurlent discharge), Age upto 9 years.

Exclusion Criteria: Punctual or canalicular abnormality, H/o previous surgery, H/o faciomaxillary trauma, cleft lip/ cleft palate or any facial deformity, acute dacryocystitis, previous history of probing. Sample size was 100 patients. Approval for the study was obtained from Ethical Committee of Institution. The type of study was prospective, interventional study. All statistical analysis was carried out with software SPSS version 2.0. A total 100 patients were enrolled in the study. The patients came with epiphora and mucous discharge in Ophthalmology out patient department or referred from other department were counselled about the study. Those parents willing to participate in the study were properly counselled and consent was taken in writing. Of these 100 patients, 40 were males and 60 
were females. Patients age ranged from 3 weeks to 2 years (mean 1.2 years). All patients were randomly selected of which 40 patients undergone eye irrigation and only 25 patients undergone. Of these patients who were referred with chief complaints of epiphora and mucous discharge, congenital nasolacrimal duct obstruction was diagnosed when resistance is felt, there was reflux of saline and mucous discharge on irrigation with saline or recurrence of symptoms in spite of the use of topical antibiotic solution and massage over the sac. Tight obstruction was considered when the surgeon had difficulty passing probe \#1 to achieve patency of LDS or the use of smaller probe size to bypass the obstruction. For confirmation of congenital nasolacrimal duct obstruction irrigation with saline was performed immediately before probing. In irrigation group, specimens for culture of nasolacrimal reflux was obtained by irrigation of sac with saline. Choice of antibiotics was done on basis of culture and sensitivity results. All procedures were performed by a single ophthalmologist. Irrigation was successful in eliminating preoperative symptoms (epiphora, discharge, increased tear lake) had disappeared with a normal dye disappearance test (DDT) and patent Jones primary test.

\section{Results}

Specimens were collected from 121 LDS in 100 patients with CNLDO with a mean age of 1.2 years. Of these 121 LDS specimens $15(14.8 \%)$ showed no growth. LDS with no growth had $100 \%$ successful probing $(\mathrm{n}=15)$. Culture positive LDS had $62.2 \%$ successful probing $(\mathrm{n}=66)$ and $26.5 \%$ successful silastic intubation $(n=40)$. On comparing CNLDO which had positive culture results to those with no growth, the odds ratio was 3.28. It was not upto a level of significance $\quad(p=0.143 ; \quad 95 \% \quad$ CI $\quad$ [4.37-25.63]. Microorganisms identified were 138 in total; 108 single microorganism in 108 cultures, two species in 9 cultures and three species in four cultures. Gram negative organisms were more as compared to gram positive in LDS specimen $(n=62,62 \%$; and $n=38,38 \%$ respectively). Table 1 shows the prevalence of different microorganism species with the success rates of probing and silastic intubation. Results of probing were superior as compared to silastic intubation. The odds ratio and corresponding confidence intervals per single and total specific microorganism infection (mixed species) showed similar values with insignificant changes. Overall probing was significantly better in results as compared to silastic intubation as seen in the Table 1.

Haemophilus influenzae and Streptococcus pneumonia were the most common microorganisms ( $\mathrm{n}=$ $56,40.5 \% ; n=37,26.8 \%$ respectively) followed by Moraxella catarrhalis $(\mathrm{n}=19,13.7 \%)$, Staphylococcus aureus $(\mathrm{n}=17,12.3 \%)$, Pseudomonas aeruginosa $(\mathrm{n}=9$, $0.65 \%$ ). Most bilateral cases showed the same culture results with an exception of patient. One patient had Haemophilus Influenzae on one side and Streptococcus pneumonia on other side, with simple NLD obstruction on both sides. The most effective local antibiotics for microorganisms organisms were bacitracin and neomycin (Table 2).

Table 1: Shows the prevalence of different microorganisms species as well as success rate of both probing and silastic intubation. Both number indicates the number of procedures carried out

\begin{tabular}{|c|c|c|c|}
\hline Type & Total & & \\
\hline & Number & Success No. (\%) & \\
\hline & & Probing & Intubation \\
\hline Haemophilus influenzae & 56 & 26 & 30 \\
\hline Streptococcus pneumonia & 37 & 24 & 13 \\
\hline Moraxella catarrhalis & 19 & 10 & 09 \\
\hline Staphylococcus aureus & 17 & 09 & 08 \\
\hline Pseudomonas aeruginosa & 09 & 05 & 04 \\
\hline & 138 & $74(53.6 \%)$ & $64(46.3 \%)$ \\
\hline
\end{tabular}

Table 2: Shows comparison of different studies dealing with microbiological profile of CNLDO

\begin{tabular}{|l|c|c|c|c|c|c|c|c|c|}
\hline Study & $\begin{array}{c}\text { No. of } \\
\text { LDS }\end{array}$ & $\begin{array}{c}\text { No. of } \\
\text { growth }\end{array}$ & $\mathbf{G m + v e}$ & $\begin{array}{c}\mathbf{G m} \\
-\mathbf{v e}\end{array}$ & Common pathogens & $\begin{array}{c}\text { Risk } \\
\text { for } \\
\text { failure }\end{array}$ & $\begin{array}{c}\text { Pthogen } \\
\text { specific risk } \\
\text { of failure }\end{array}$ & $\begin{array}{c}\text { Success } \\
\text { Rate }\end{array}$ & $\begin{array}{c}\text { Antibiotic } \\
\text { Sensitivity }\end{array}$ \\
\hline Kuchar et al & 50 & 30 & 49.3 & 50.7 & $\begin{array}{c}\text { Streptococcus } \\
\text { Pneumonia }(35.4 \%) \\
\text { Hemophilus Influenza } \\
(19.6 \%)\end{array}$ & N/A & N/A & N/A & $\begin{array}{c}\text { Yes } \\
\text { (Bacitracin } \\
\& \\
\text { Neomycin) }\end{array}$ \\
\hline Usha et al & 238 & 17 & 57 & 43 & $\begin{array}{c}\text { Streptococcus } \\
\text { pneumonia (32.7\%) } \\
\text { Hemophilus influenza } \\
(31.3 \%)\end{array}$ & N/A & N/A & N/A & $\begin{array}{c}\text { Yes } \\
\text { (Ofloxacin) }\end{array}$ \\
\hline
\end{tabular}




\begin{tabular}{|c|c|c|c|c|c|c|c|c|c|}
\hline $\begin{array}{l}\text { Gerkowicz } \\
\text { et al. }\end{array}$ & 81 & 25 & 70 & 28.8 & $\begin{array}{c}\text { Staphylococcus } \\
\text { epidermis }(28 \%) \\
\text { Staphylococcus aureus } \\
(22 \%) \\
\end{array}$ & N/A & N/A & N/A & N/A \\
\hline $\begin{array}{l}\text { MacEwen et } \\
\text { al }\end{array}$ & 151 & 79 & 35 & 65 & $\begin{array}{c}\text { Hemophilus influenza } \\
(55 \%) \text { Staphylococcus } \\
\text { aureus }(35 \%)\end{array}$ & No & N/A & N/A & N/A \\
\hline Kim et al & 50 & 36 & 56.2 & 43.8 & $\begin{array}{c}\text { Staphylococcus aureus } \\
(25 \%) \text { Pseudomonas } \\
\text { aeruginosa }(15.6 \%)\end{array}$ & No & N/A & $\begin{array}{l}\text { Irrigatio } \\
\text { n }(96 \%) \\
\text { Probing } \\
(84.6 \%)\end{array}$ & $\begin{array}{c}\text { Yes } \\
\text { (Ciprofloxa } \\
\text { cin) }\end{array}$ \\
\hline $\begin{array}{l}\text { Al-Faky } \\
\text { et al }\end{array}$ & 181 & 12.1 & 49.1 & 50.9 & $\begin{array}{c}\text { Streptococcus } \\
\text { pneumonia }(48.1 \%) \\
\text { Haemophilus influenza } \\
(39.2 \%)\end{array}$ & No & Yes & $\begin{array}{c}\text { Probing } \\
(76.6 \%) \\
\text { Intubati } \\
\text { on } \\
(82.1 \%) \\
\end{array}$ & $\begin{array}{c}\text { Yes } \\
\text { (Bacitracin } \\
\& \\
\text { Neomycin) }\end{array}$ \\
\hline $\begin{array}{l}\text { Our } \\
\text { Study }\end{array}$ & 121 & 138 & 76 & 62 & $\begin{array}{c}\text { Haemophilus influenza } \\
(40.5 \%) \text { and } \\
\text { Streptococcus } \\
\text { pneumonia }(26.8 \%)\end{array}$ & N/A & N/A & N/A & $\begin{array}{c}\text { Yes } \\
\text { (Bacitracin } \\
\& \\
\text { Neomycin) }\end{array}$ \\
\hline
\end{tabular}

\section{Discussion}

Congenital nasolacrimal duct obstruction results in stagnation of fluid within the lacrimal sac area which causes secondary bacterial infection. Sources of bacterial infection can be from normal conjunctiva, upper respiratory tract, birth canal in the neonates. The study was conducted to assess microorganisms causing congenital nasolacrimal duct obstruction. To see efficacy of probing as compared to silastic intubation. The efficacy of each procedure was assessed to see treatment in patients of congenital nasolacrimal duct obstruction as a primary modality. Previous study conducted showed only bacteriology profile in CNLDO with possible impact on the success rate in culture positive results ${ }^{14}$. On the contrary our study showed that Haemophilus influenzae and Streptococcus pneumonia were the most common microorganisms ( $\mathrm{n}=$ $56,40.5 \% ; n=37,26.8 \%$ respectively) in CNLDO. This is similar to the results of study conducted by Kuchar et al. (19.6\% and 35.4\%) and Usha et. al $(32.7 \%$ and $31.3 \%$ ) Microbial infection initiates an immune-system response and tissue reaction caused by elaboration of different mediators that end up with fibrosis. The same was confirmed by histopathologic study of chronic dacryocystitis. ${ }^{16}$ The prevalence of CNLDO with no growth shows the sole effect of congenital anomaly on the degree of tightness. Probing was as significantly better as silastic intubation in patients of congenital nasolacrimal duct obstruction with success rate of $53.7 \%$. It is a successful primary procedure in treatment of CNLDO. Probing and silastic intubation were performed in similar age groups in LDS-infected cases with Staphylococcus aureus, which eliminates the effect of age as a risk factor. Also probing is a simple operative procedure easily performed in children under sedation of anaesthesia or sometimes under general anaesthesia in uncooperative patients. ${ }^{18.19}$ In contrast to silastic intubation which is complex, time consuming, requiring more resources and often involves complications during and after surgery. Studies have given success rate of probing to be $82 \%$ in relieving symptoms. ${ }^{19,20}$ In our study the result of efficacy of probing came out to be $53.7 \%$. Probing is a simple, quick, cost effective, dry case procedure and do not require compromise the patient for future nasolacrimal surgery. ${ }^{20} \mathrm{~A}$ simple probing procedure is effective in do not producing symptomatic improvement, when limited to use in patients with complete obstruction of nasolacrimal duct and when watering is the only symptom. $^{21}$

\section{Conclusion}

The micobiological study of CNLDO may have a value in predicting the obstruction. Identification of microorganisms works as an encouraging factor for early intervention of the cases. As in whole results of probing were superior to that of silastic intubation. So we recommend probing as a primary treatment of modality in patients of congenital nasolacrimal duct obstruction. We do not recommend any procedure (probing, silastic intubation) in relation to organisms as these field needs more study with more sample size and each procedure has its own advantage and disadvantages.

\section{References}

1. Nesi F.A., Lishman R.D., Levine M.R. Ophthalmic plastic and reconstructive surgery. 2nd ed. St. Louis: Mosby-Year Book, Inc.; 1998. (Congenital lacrimal disorders)

2. Paul T.O. Medical management of congenital nasolacrimal duct obstruction. $J$ Pediatr Ophthalmol Strabismus. 1985;22:68-70.

3. Pediatric Eye Disease Investigator Group. Primary treatment of nasolacrimal duct obstruction with balloon catheter dilation in children younger than 4 years of age. J AAPOS 2008;12(4):451-55.

4. Casady D.R., Meyer D.R., Simon J.W., Stasior G.O., Zobal-Ratner J.L. Stepwise treatment paradigm for 
congenital nasolacrimal duct obstruction. Ophthal Plast Reconstr Surg. 2006;22(4):243-247.

5. Hartikainen J., Lehtonen O., Saari K.M. Bacteriology of lacrimal duct obstruction in adults. BJO. 1997;81:37-40.

6. Usha K., Smitha S., Shah N., Lalitha P., Kelkar R. Spectrum and the susceptibilities of microbial isolates in cases of congenital nasolacrimal duct obstruction. $J$ AAPOS. 2006;10(5):469-472.

7. Gerkowicz M., Koziol-Montewka M., Pietraś-Trazpiel M., Kosior-Jarecka E., Szczepanik A., Latalska M. Identification of bacterial flora of conjunctival sac in congenital nasolacrimal duct obstruction in children. Klin Oczna. 2005;107(1-3):83-85.

8. Kuchar A., Lukas J., Steinkogler F.J. Bacteriology and antibiotic therapy in congenital nasolacrimal duct obstruction. Acta Ophthalmol Scand. 2000;78(6):694698.

9. Bareja U., Ghose S. Clinicobacteriological correlates of congenital dacryocystitis. Indian J Ophthalmol. 1990;38(2):66-69.

10. Kim Y.S., Moon S.C., Yoo K.W. Congenital nasolacrimal duct obstruction: irrigation or probing? Korean J Ophthalmol. 2000;14(2):9096. [PubMed]

11. MacEwen C.J., Phillips M.G., Young J.D. Value of bacterial culturing in the course of congenital nasolacrimal duct (NLD) obstruction. J Pediatr Ophthalmol Strabismus. 1994;31(4):246-250.

12. Katowitz J.A., Welsh M.G. Timing of initial probing and irrigation in congenital nasolacrimal duct obstruction. Ophthalmology. 1987;94(6):698-705.

13. Blicker J.A., Buffam F.V. Lacrimal sac, conjunctival, and nasal culture results in dacryocystorhinostomy patients. Ophthal Plast Reconstr Surg. 1993;9(1):43-46.

14. Bale R.N. Dacryocystitis: bacteriological study and its relation with nasal pathology. Indian $J$ Ophthalmol. 1987;35(4):178-182.

15. Tucker N., Chow D., Stockl F., Codère F., Burnier M. Clinically suspected primary acquired nasolacrimal duct obstruction: clinicopathologic review of 150 patients. Ophthalmology. 1997;104(11):1882-1886.

16. Salour H., Hatami M.M., Parvin M., Ferdowsi A.A., Abrishami M., Bagheri A. Clinicopathological study of lacrimal sac specimens obtained during DCR. Orbit. 2010;29(5):250-253.

17. Morgan M. Staphylococcus aureus, Panton-Valentine leukocidin, and necrotising pneumonia. A rare but often lethal cocktail that can complicate flu. BMJ. 2005;331(7520):793-794.

18. Bonderman D., Jakowitsch J., Redwan B., Bergmeister H., Renner M.K., Panzenböck H. Role for staphylococci in misguided thrombus resolution of chronic thromboembolic pulmonary hypertension. Arterioscler Thromb Vasc Biol. 2008;28(4):678-684.

19. Aguilar J., Urday-Corneio V., Donabedian S., Perri M., Tibbetts R., Zervos M. Staphylococcus aureusmeningitis: case series and literature review. Medicine (Baltimore) 2010;89(2):117-125

20. Aasen A.O., Wang J.E. Mediator responses in surgical infections. Surg Infect (Larchmt) 2006;7(Suppl. 2):S3S4.

21. Gomez M.I., O’Seaghdha M., Magargee M., Foster T.J., Prince A.S. Staphylococcus aureus protein A activates TNFR1 signaling through conserved IgG binding domains. J Biol Chem. 2006;281:20190-20196.

22. Saif MW, Dai T. Mitomycin-induced interstitial pneumonitis in a patient with brca2 associated metastatic pancreatic carcinoma. JOP 2010;11(3):277-79 [Online].
23. McMillan J.A., Feigin R.D., DeAngelis C., Jones M.D. 4th ed. Lippincott Williams \& Wilkins, Inc.; Philadelphia, USA: 2006. Oski's pediatrics: principles \& practice.

24. Bannerman D.D., Paape M.J., Goff J.P., Kimura K., Lippolis J.D., Hope J.C. Innate immune response to intramammary infection with Serratia marcescens and Streptococcus uberis. Vet Res. 2004;35(6):681-700.

25. Makimura Y., Asai Y., Sugiyama A., Ogawa T. Chemical structure and immunobiological activity of lipid A from Serratia marcescens LPS. $J$ Med Microbiol. 2007;56:1440-1446. 